\title{
Why is it so hard to belong? The difficulties of refugees in their integration processes within Brazilian society and labor market
}

\author{
ana Christina Celano Teixeira ${ }^{1}$ \\ Eliana CRISTINA MotTa da SILVA ${ }^{1}$ \\ Daniela Longobucco TeIXeira Balog ${ }^{2}$ \\ BIANCA SÁ ${ }^{3}$
}

\author{
${ }^{1}$ FACULDADES IBMEC, RIO DE JANEIRO - RJ, BRAZIL \\ 2 UNIVERSIDADE DO GRANDE RIO (UNIGRANRIO), RIO DE JANEIRO - RJ, BRAZIL \\ ${ }^{3}$ Fundação Getulio VARgas (FGV EBAPE) / Escola BrasileIRA de AdMINISTRAÇÃo PúblicA E de EMPRESAS, RIO DE JANEIRO - RJ, BRAZIL
}

\begin{abstract}
The world has recently witnessed a social phenomenon that has been present during the entire history of humanity, but has now taken on greater proportions and impact: the large population displacements of refugees. According to the United Nations, more than 75 million people were in this situation worldwide at the end of 2017, a figure never observed before (UNHCR, 2017). Since 1951, more than 147 countries, including Brazil, have signed the United Nations Refugee Convention, which established obligations for signatory governments to provide refugees with legal and safe working conditions. Considering this context, this study aims to investigate the perceptions of refugees of different origins regarding the processes and difficulties of integrating into Brazilian society and labor market. The processes deal with bureaucratic barriers, cultural differences, ethnic-racial issues, and language, among others. The study uses a qualitative approach consisting of eight interviews in the city of Rio de Janeiro with refugees of a variety of nationalities and both genders. The results show that these respondents perceive a gap between public policies and practices involving refugees in the workplace, and also discrimination by the population, employers, and authorities, describing a multicultural rather than an intercultural context. Despite these challenges, respondents say they intend to continue living and working in Brazil.
\end{abstract}

Keywords: Refugee. Globalization. Labor market. Multiculturalism.

Por que é tão difícil pertencer? As dificuldades dos refugiados em seus processos de inserção no mercado de trabalho e na sociedade brasileira

\begin{abstract}
Resumo
O mundo tem assistido a um fenômeno social presente na história da humanidade desde seus primórdios, mas atualmente com proporções e impactos ainda desconhecidos: os grandes deslocamentos populacionais, envolvendo pessoas que passam a ser classificadas como refugiados. De acordo com a ONU, mais de 75 milhões de pessoas se encontravam nesta situação em todo o mundo no final de 2017, uma quantidade jamais vista anteriormente (UNHCR, 2017). Desde 1951, mais de 147 países, dentre eles o Brasil, assinam o Estatuto dos Refugiados da Convenção das Nações Unidas que estabelece obrigações aos governos signatários para que ofereçam aos refugiados condição de trabalho legal e seguro. Desta forma, este estudo tem por objetivo investigar a percepção dos refugiados de diferentes origens sobre os processos e as dificuldades de inserção na sociedade brasileira e em seu mercado de trabalho. Os processos em foco tratam de temas como as barreiras burocráticas, as diferenças culturais, as questões étnico-raciais e o desconhecimento do idioma, entre outros Para a condução da pesquisa, optamos pela metodologia qualitativa, por meio de entrevistas em profundidade, realizadas no Rio de Janeiro, com refugiados de diferentes nacionalidades, de ambos os gêneros. Entre os principais resultados, nota-se a existência de uma distância entre as políticas públicas e as práticas que envolvem os refugiados no meio laboral; além da discriminação sentida pelos entrevistados por parte da população, empregadores e autoridades, o que apontou um contexto multicultural e não intercultural. Apesar dos desafios os entrevistados dizem pretender continuar vivendo e trabalhando no Brasil.
\end{abstract}

Palavras-chave: Refugiado. Globalização. Mercado de trabalho. Multiculturalismo.

\begin{abstract}
¿Por qué es tan difícil pertenecer? Las dificultades de los refugiados en sus procesos de inserción en el mercado laboral y en la sociedad brasileña

Resumen

El mundo ha sido testigo de un fenómeno social presente en la historia de la humanidad desde sus inicios, pero actualmente con proporciones e impactos aún desconocidos: los grandes desplazamientos poblacionales, que involucran a personas que ahora están clasificadas como refugiados. Según la ONU, más de 75 millones de personas se encontraban en esta situación en todo el mundo a fines de 2017, una cantidad nunca antes vista (UNHCR, 2017). Desde 1951, más de 147 países, incluso Brasil, han firmado el Estatuto de los Refugiados de la Convención de las Naciones Unidas, que establece obligaciones para los gobiernos signatarios de ofrecer a los refugiados condiciones de trabajo legales y seguras. Así, este estudio tiene como objetivo investigar la percepción de los refugiados de diferentes orígenes sobre los procesos y las dificultades de inserción en la sociedad brasileña y en el mercado laboral. Los procesos en foco abordan temas como las barreras burocráticas, las diferencias culturales, los problemas étnico-raciales y el desconocimiento del idioma, entre otros. Para realizar la investigación, optamos por la metodología cualitativa, a través de entrevistas en profundidad, realizadas en la ciudad de Río de Janeiro, con refugiados de diferentes nacionalidades, de ambos géneros. Entre los principales resultados, se observaron una distancia entre las políticas públicas y las prácticas que involucran a los refugiados en el medio laboral; además de la discriminación que sienten los entrevistados por parte de la población, los empleadores y las autoridades, lo que señaló un contexto multicultural y no intercultural. A pesar de los desafíos, los entrevistados dicen que tienen la intención de seguir viviendo y trabajando en Brasil.
\end{abstract}

Palabras clave: Refugiado. Globalización. Mercado laboral. Multiculturalismo. 


\section{INTRODUCTION}

The world has recently witnessed a social phenomenon that has been present during the entire history of humanity, but has now taken on greater proportions and impact: the large population displacements of refugees (Andrade, 1996; Moreira, 2005; Póvoa \& Ferreira, 2005). According to the United Nations, more than 75 million people were in this situation worldwide as of the end of 2017, a figure - never observed before (United Nations High Commissioner for Refugees [UNHCR], 2017).

In this model, human mobility currently produces and reproduces international inequalities arising from the globalization process (Santos, 2003). For some, mobility has been facilitated, while for others it is profoundly risky. At the same time that one sees the emergence of cost and time efficient electronic visas, biometric passports and modes of transport, it is also possible to see migratory processes by dangerous routes marked by scarce resources and deep uncertainties and privations upon these immigrants' arrival at their desired destinations (Bauman, 1998, 2016).

According to the 1951 United Nations Refugee Convention, "a refugee is any person who, because of well-founded fears of persecution due to his race, religion, nationality, membership of a particular social group and political opinion stays outside his country of origin, and because of these fears he cannot or will not return to it " (UNHCR, 2000, p. 76). It is worth noting that this convention, which has been signed by 147 countries, including Brazil, establishes obligations for signatory governments to provide refugees with legal and safe working conditions, as well as access to the country's public service network (UNHCR, 2004).

Data from the National Committee for Refugees (COMITÊ NACIONAL PARA OS REFUGIADOS [CONARE], 2020), an organ of the Brazilian Ministry of Justice, indicate that the country had as of October 2018, 10,665 refugees from 90 different nations. In December 2019, more than 21,432 Venezuelans were recognized as refugees through a prima facie procedure approved by the CONARE Plenary Meeting, thus bringing the number of recognized refugees in Brazil to about 32 thousand people (CONARE, 2020). Considering only Rio de Janeiro, there were 4,152 recognized refugees as of 2016, and 2,618 awaiting refuge. In 2018, 752 asylum applications were registered in the state (ACNUR, 2018). Currently in Brazil, most members of this group are young people between 18 and 29 years old who are in their productive phase as workers (CONARE, 2016).

In terms of absorbing these refugees into the local labor market, we are presented with the scenario depicted by Moulin (2013), in which this group is mostly compelled to accept jobs for which no specific training is required. Previous experience and academic education in their original countries, therefore, have not been recognized, despite the existence of public and private initiatives aimed at favoring their recognition (Moreira, 2005). In Brazil, the few existing records of support for incorporating refugees into the labor market relate mostly to Portuguese courses and entrepreneurship incentives, with the latter being an exclusive initiative sponsored by the city of São Paulo (CONARE, 2016).

Thus, this study aims to investigate the perception of refugees of different origins about the processes and difficulties of integrating into Brazilian society and its labor market. The processes under focus deal with topics such as bureaucratic barriers, cultural differences, ethnic-racial issues and language, among others. We have adopted a qualitative approach for this study, interviewing refugees individually with a semi-structured script in the city of Rio de Janeiro. These refugees come from a variety of nations and both genders, and have lived and worked in this city.

Apart from the fact that the relevance of this theme is, a priori, irrefutable due to its humanitarian nature (Hall, 2008; Nkomo, Bell, Roberts, Joshi \& Thatcher, 2019; Zanini, Póvoa \& Santos, 2013), we hope that this study will foster a new broad spectrum of research, especially in the organizational studies and people management areas, including interdisciplinary work with the areas of international relations, psychology, social sciences, anthropology, human geography and law, among others (Póvoa \& Ferreira, 2005).

Also, we hope that the results found here can help individuals, refugee groups, public and private organizations in the country, and society as a whole, in stimulating reflection and debate, and enabling social transformation towards greater equality, inclusion and respect for peoples' differences. 


\section{THEORETICAL REFERENCE}

\section{Globalization, migratory and refugee movements}

Refugees constitute a specific group in the international migration process. According to Moreira (2010), these are individuals forced out of their countries because of intra- or interstate conflicts, due to ethnically, religiously, or politically repressive regimes or other contexts of violence and human rights violations. With respect to this definition, other researchers highlight the need to broaden it, to include other reasons for migration such as the risk of torture, capital punishment, environmental disasters and a lack of natural resources, which suggest recognizing different migrant categories, such as economic, humanitarian, environmental and climate refugees (Berchin, Valduga, Garcia, Salgueirinho \& Guerra, 2017).

Within the globalization context, this migratory movement faces a remarkable discrepancy between discourse and practice. According to Pellegrino (2003, p. 8):

The liberal policy in regard to capital and commodity movements supported by most central states contradicts the severe controls imposed on the free mobility of workers and the fixation of people within their national territories.

Thus, Pellegrino (2003) states that despite the idea of "free mobility of people" included in the definition of "globalization", in practice refugees have cannot travel freely across geographic borders.

According to data from the United Nations High Commission for Refugees (UNHCR, 2019), by the end of 2019 there were 79.5 million people forcibly displaced worldwide as a result of persecution, conflict, violence or violations of human rights. Of this total, 26 million are considered refugees, 45.7 are still in their countries and the remaining 4.2 million are seeking asylum. Out of all refugees, $68 \%$ of this total comes from five countries - Syria, Venezuela, Afghanistan, South Sudan and Myanmar.

Moreover, within this context, there is also an important distinction between hegemonic globalization and antihegemonic globalization. The first leads to a disruption of economically and culturally dominated peoples, while the second is marked by the struggle against localized globalism and the structural violence that imposes itself against cultures and against these oppressed peoples. Indeed, one may consider that there is a set of globalization processes that ultimately is contradictory. Many of these contradictions have arisen forcibly from intense population displacements (Santos, 2006).

Some time ago, even before the intense "migratory crisis" or the current awareness of the new state of human "globality", Hobsbawm (2017, p. 145) pointed out that:

The processes of industrialization and urbanization, sustaining themselves, as they do, in massive and multifarious movements, in people migration and displacement, undermine the basic nationalist assumption of a territory inhabited essentially by an ethnically, culturally and linguistically homogeneous population. The harsh xenophobic or racist reaction from the native population of the countries or regions receiving the influx of "strangers" has unfortunately been usual in the United States since the 1890s, and in Western Europe since the 1960s. But xenophobia and racism are symptoms, not medicine. In modern societies, communities and ethnic groups are bound to coexist, despite the rhetoric that dreams of returning to a nation without mixed populations.

In this way, in the 21st century, in the so-called era of liquid modernity, societies no longer seem to be able to resist this phenomenon. After all, it would be like resisting one's own irrefutable globalization (Bauman, 2016). However, according to Hobsbawm $(1995,2017)$, there is still in most countries, especially those receiving migratory movements, the emergence of small island archipelagos where resistance is formed by means of ethnic identity movements that actually seem to be reactions to weakness and fear, and they erect social barricades to keep the forces of the modern or postmodern world away.

Thus, within the framework of contemporary globality, made denser by the massive mobility of population groups, hospitality emerges as a solution that represents not the principle of philanthropy, but of law. From Kant it can be defined that "cosmopolitan law must be limited to the conditions of universal hospitality." Which, according to Kantian precepts, means that every foreigner must have a guaranteed right not to be treated in a hostile manner by being in a foreign territory. 
After all, all men should be entitled to the common property of the earth's surface, and human beings cannot stay forever on its finite spherical surface, but rather need to tolerate each other, since there is no one originally with more rights to be in a certain place on Earth than another (Santos, 2006).

Following this same principle, Bauman (2016) emphasizes that the distinction between land or countries should not be claimed, but rather the right of human beings to associate and establish communication and connection in a beneficial way to all. What should happen is the replacement of hostility with hospitality.

\section{Migratory movements and the concepts of multiculturalism and interculturality}

For better or for worse, in an increasingly globalized world the issue of differences between human beings occupies a fundamental place in current discussions, dealing with issues such as respect, identity and equality among people. When talking about groups of people who are forced to move from their home countries, it is necessary to understand the relationships that are established under the concepts of inclusion and diversity in their new local realities within the countries that have welcomed them (Nkomo et al., 2019).

Societies in central or even peripheral countries, such as Brazil, which receive flows of migrants have never been immune to the conflicts generated by these movements, and one of the causes of this may be based on the insufficiency of an intercultural or even a multicultural model to account for the complexity inherent in an environment permeated by differences (Rodrigo, 2012). In this sense, it is necessary to examine the two of them more closely.

In the social context of multiculturalism, different groups coexist in an environment that tends towards tolerance, although there is largely an implicit right to maintain differences, which in fact hides the advantages of dominant groups over minorities (Rodrigo, 2012). It is important that the word "tolerance" be reinforced in the understanding this concept, as it presupposes the existence of people who need to be tolerated, that is, who in fact do not occupy a social role of equality and inclusion. In this dimension, power relationships remain clearly delineated, where some social actors overlap others, whether this is in terms of economic terms, rights, recognition or influence (Westwood \& Jack, 2009).

However, Rodrigo (2012) argues that the standards of recognition, respect and appreciation of cultural diversity can only be obtained within the dimension of interculturality. This is so because it is only within this context that ethnocentrism is broken and there appears a real interest and interaction with others' cultures. Conflict may also be present in the intercultural dimension, but there will be spaces for coexistence, beginning with an acceptance of otherness and from frank and symmetrical dialogue.

Moreover, one of the main traits of interculturality is the demand for recognition, which must be represented by the voices and needs of minority groups. Honneth (2009) argues that society will always live under a state of pressure, but this will be the way in which it will interpret the fight for recognition, understood as a necessary and legitimate type of tension which allows new conditions for participation in public life. Thus, all social actors, including minority groups such as refugees, must take part in the public sphere and in organizations. In an intercultural reality, they need to have space for expression and respect in order to articulate their needs and influence social discussions in a real way.

Aiming to question the existence of a multicultural or an intercultural environment in Brazil today, it is relevant to analyze the presence of foreigners in the face of the formation of a national social identity in a historical way. Seminal Brazilian social science scholars in this field such as Gilberto Freyre, Sergio Buarque de Holanda, Florestan Fernandes and Darcy Ribeiro provide us with different perspectives.

For example, Gilberto Freyre (2006) describes the Brazilian from the point of view of the colonizers (Portuguese), indigenous (Native American) and black (African) social and cultural relationships which formed our society, although there never was an egalitarian coexistence. This lack of egalitarian coexistence reveals an environment much closer to the multiculturalism dimension.

There is a romantic perspective in Freyre's argument, which has received some criticism (Ribeiro, 2017). Most of this comes from the fact that there were hegemonic standards that subjected minority groups to explicit and veiled forms of violence, which were disregarded by Freyre, and these processes have occurred since the time of slavery, which lasted around 350 years in Brazil, leaving marks that cannot be forgotten by modern society (Almeida, 2019; Ribeiro, 2017). 
Why is it so hard to belong? The difficulties of refugees in their integration processes within Brazilian society and labor market
Ana Christina Celano Teixeira | Eliana Cristina Motta da Silva Bourry Daniela Longobucco Teixeira Balog | Bianca Sá

Among the critics, we may also note the work of Florestan Fernandes, who rejected Freyre's ideology of racial democracy, since it masked a conflict of races and classes, in addition to the contradictions and dilemmas existing in Brazil (Freitag, 2005). In fact, Brazil might deliver a mistaken impression of being a less prejudiced and more egalitarian country than it is, what would deviate even more from the concept of interculturality and, at best, approach the model of multiculturalism.

With respect to Sergio Buarque de Holanda (2014), it is interesting to mention that he describes the Brazilian as a cordial man, with an affectionate behavior, not necessarily sincere, but always referring to family and personal relationships. In this case, it is important to note that because the word cordial is derived from 'cord' or 'core' which means heart, this concept is often wrongly attributed to pleasant, kind behavior that would produce a friendly and inclusive environment for everybody. However, what Holanda argues is that this cordial man has passionate attitudes, but they are strictly related to a closed circle of friends and relatives, which makes it difficult, in fact, to include strangers in this group. It is up to us to ask: do foreigners (and especially refugees) receive the same family treatment?

In particular, Darcy Ribeiro (2019, p. 183) highlights the Brazilian nationalist vainglory, stating that "our country has such a sap of uniqueness that it makes it extremely difficult to accept and enjoy living with other peoples". And, to reinforce the challenge, he states that Brazil is a country marked by so many inequalities that it is, indeed, a set of different social islands.

Thus, these concepts should fortify a national tendency in favor of acceptance, but it is limited in the multicultural sense of tolerating the different and being open to diversity, but it does not really means that the nation is open to promoting the fair inclusion of the different on an equal social and economic basis. Since its origin, Brazil has dealt with all kinds of people coming from different places and belonging to different ethnicities, but this does not guarantee an intercultural environment, as defined by Rodrigo (2012).

\section{Brazil in the migratory scenario}

Since the Portuguese colonization period, several migratory policies have been implemented in Brazil to attract workers and expand the occupation of the nation's territory (Amaral \& Fusco, 2005). When the international refugee regime was being constructed after World War II, Brazil adopted a migration policy under the Vargas administration which aimed to attract European workers to the agricultural sector and to a lesser extent industry (Moreira, 2012). Thus, the country did not hesitate to participate in the initiatives proposed by the international community to address the refugee problem, because it understood that refugees were not only a humanitarian issue, but also a political and economic instrument. Brazilian policies, therefore, were based on national and humanitarian interests (Haydu, 2009; Moreira, 2012).

The foreigners' right of refuge, guaranteed by the UN Convention of 1951, was ratified by Brazil in 1997. According to the Ministry of Justice (2010), any foreigner who has any fear of persecution - if properly founded - of a racial, religious, political, or national nature or due to belonging to a particular social group, as well as those who have been forced to leave their country of origin because of a serious and widespread violation of human rights, can apply for refugee status.

Brazil, a signatory of the principal international human rights treaties, has created an institutional structure to analyze and judge refugee status requests - the National Committee for Refugees (CONARE) - which includes members of the government, civil society and a representative of UNHCR.

According to Committee data, refugee status requests in the country grew by 2,868\% from 2010 to 2015, going from 966 in 2010 to 28,670 in 2015. In 2017, the country had 8,950 refugees of 79 different nationalities. The largest recognized refugee community in Brazil is that of the Syrians (2,480 refugees, more than 25\% of the total), followed by Angolans, Colombians, Congolese, Palestinians and Venezuelans. At this time, Brazil still had 1,468 resettled people, that is, foreigners who had refuge in one country, but due to some circumstances had to migrate to a third country. Together with the refugees, this totals 10,418 people. In 2017, there were also another 25 thousand foreigners awaiting responses to their requests (CONARE, 2016).

According to the 2017 CONARE statistics, of the total number of refugees in Brazil, $71 \%$ are men and $29 \%$ are women. Regarding age groups, the distribution is as follows: (1) $14 \%$ are from 0 to 12 years old, (2) $6 \%$ are from 13 to 17 years old; (3) 33\% are 
Why is it so hard to belong? The difficulties of refugees in their integration processes within Brazilian society and labor market
Ana Christina Celano Teixeira | Eliana Cristina Motta da Silva Bourry Daniela Longobucco Teixeira Balog| Bianca Sá

from 18 to 29 years old; (4) 44\% are from 30 to 59 years old; and (5) 3\% are over 60 years old. According to CONARE (2019), the number of refugees has increased almost fivefold in the last three years. This balance reflects the humanitarian crisis in Venezuela. $77 \%$ of refuge requests currently originate from that country.

\section{Current scenario of refugees in Rio de Janeiro}

In 2017, Rio de Janeiro hosted about 3,000 refugees and in 2018, 752 asylum applications were registered in the state (ACNUR, 2018). Recent statistics from the National Committee for Refugees (CONARE) show that the state of Rio de Janeiro accounts for a significant proportion of refugees with official status, including refugee applicants and humanitarian visa holders.

The entire bureaucratic-administrative apparatus connected with refugees affects urban centers in the state of Rio de Janeiro and elsewhere. Refugees need to prove that they are in a refugee situation. While they are applying, they are in a non-citizen limbo. Thus, the city becomes a large area of control and urban conditions added to refugee conditions produce and reproduce territorial boundaries, separating specific areas (ghettos) for these groups and reinforcing racial, ethnic, national, and gender prejudices that materialize in the interactions with these groups (Paiva, Dias \& Moulin, 2018).

However, Brazil and, specifically, the state of Rio de Janeiro, still have the aggravating crisis of the Brazilian and state economy, which began in 2014 and its consequences are still being felt today. The Brazilian crisis has been caused by a series of supply and demand shocks, mostly caused by errors in public policies, which according to Barbosa (2017) have reduced the country's economy growth capacity, generating a high fiscal cost. Thus, according to 2019 IBGE statistics, Brazil in March 2019 had an unemployment rate of $12.7 \%$, affecting 13.5 million Brazilians. And in the case of Rio de Janeiro, one can observe the second largest increase in the number of informal workers in the country, from 494 thousand people in 2014 to 1.2 million in 2017. This group represents individuals without a formal job who cannot even be named "unemployed", because that classification (informal workers) refers to people who no longer seek a formal job in the production chain (Instituto Brasileiro de Geografia e Estatística [IBGE], 2019).

\section{METHODOLOGY}

This study adopts a qualitative approach, a method that according to Creswell $(2010$, p. 26) "is a means for exploring and understanding the meaning that individuals or groups attach to a social or human problem." With this exploratory focus, this study deals with issues and procedures that have emerged from data collected from the respondents.

The selection of subjects was by made by convenience according to the snowball method (Aaker, Kumar \& Day, 2009). All interviews were conducted between October and December 2018, and the number of subjects was determined by data saturation (Bauer \& Aarts, 2002; Gaskell, 2002). The names of the respondents were kept confidential. Box 1 below presents a detailed profile of the research respondents.

Box 1

Refugees Profiles

\begin{tabular}{|c|c|c|c|c|c|c|}
\hline Refugee & Origin & Age & Gender & $\begin{array}{c}\text { Period } \\
\text { in } \text { rj }\end{array}$ & Degree & $\begin{array}{c}\text { Area of education in the } \\
\text { country of origin }\end{array}$ \\
\hline R1 & Angola & 33 & Female & 3 years & Incomplete undergraduate & Administration/ it \\
\hline R2 & Morocco & 32 & Male & 1,7 years & Master of science & Marketing \\
\hline R3 & Venezuela & 29 & Male & 4 years & Undergraduate & Education \\
\hline R4 & Congo & 37 & Male & 10 years & Undergraduate & Nursing \\
\hline R5 & Venezuela & 53 & Female & 3 years & High school & - \\
\hline R6 & Venezuela & 50 & Male & 3 years & Undergraduate & Engineering \\
\hline R7 & Gambia & 30 & Female & 4 years & & - \\
\hline R8 & Haiti & 37 & Female & 8 years & Doctor of science & Antropology \\
\hline
\end{tabular}

Source: Elaborated by the authors. 
Why is it so hard to belong? The difficulties of refugees in their integration processes within Brazilian society and labor market
Ana Christina Celano Teixeira | Eliana Cristina Motta da Silva Bourry Daniela Longobucco Teixeira Balog| Bianca Sá

Data analysis was performed using the NCT method - notifying things, collecting things and thinking about things, as suggested by Friese (2014). The first step (noticing) involved a first reading and exploration of the research material, moving on to a second phase (collecting) for coding the related data segments. And, finally, based on the previous codification, an analysis was made (thinking) from the perspective of the research questions.

The interviews were recorded with the respondent's permission, resulting in a total audio of 870 minutes. After this step, the material was transcribed into a forty-two-page text which has been used as the basis for analyzing the data.

The analysis of the results based on the collected material was done in an interpretative and inductive manner. According to Creswell (2010) in terms of interpretation, one cannot separate the researchers' interpretations from their origins, history, contexts and previous understandings. Consequently, the researcher's role should not be taken as completely neutral.

The analysis was performed in three emerging categories: (1) Migration process to the Brazilian labor market, (2) Main obstacles to entering the Brazilian labor market and (3) Social networking with other refugees as a means of facing these obstacles.

\section{DATA ANALYSIS}

\section{Migration process to the Brazilian labor market}

Difficulties in scheduling interviews seemed to foreshadow the difficulties from all sides that afflict refugees before and after their arrival in Brazil. In this process, refugees generally expressed fear in scheduling meetings, speaking and exposing their current and past lives. When they finally agreed to contribute to the research, they confirmed, in most of their statements, this feeling of insecurity, the pain of loss, the difficulties of recent changes and the feeling of helplessness regarding the present in a strange land, which have often left them hopeless and without the patience for interviews (Paiva, Dias \& Moulin, 2018). In the interviews, they reported moments of their lives in their original countries marked by suffering and discouragement.

(...) When I was 15, I was taken to Senegal in order to get married and by the time I was 17, I already had a daughter. I escaped from my husband and left my daughter in the beginning with an aunt and afterwards with my mother (the respondent told us with a lot of difficulty and fear) (R7).

(...) I thought of leaving my country in 2007 after the elections due to the conflict. I received direct threats against my life. Other people have been arrested. I belonged to an organization that defended the Congo. My family and a friend helped me buy a ticket to come here to Brazil. I wanted to leave to save my life (R4).

I am trying to face the challenges here and forget my past sorrows (R2).

Thus, these statements reveal that as pointed out by Bauman (2017) and Santos (2006), human mobility in the $21^{\text {st }}$ century is made up of different facets and the worst of them are reinforced by unprecedented levels of social inequality and injustice in the "world without borders".

The researchers' difficulties in making the refugees comfortable during the interviews is indicative of how delicate the situation of being a refugee seems to be in a foreign country and how interactions with local people are contaminated by fear, especially hostility (Santos, 2006).

This observation seems to indicate in this situation an absence of the Kantian precept that guarantees any foreigner the right not to be treated in a hostile manner when in a foreign territory (Santos, 2006). After all, all men should have the right to common ownership of the earth's surface. Based on this basic universal principle we should at least tolerate each other within a multicultural perspective (Westwood \& Jack, 2009).

With this in mind and returning to the interviews, the reasons that the interviewees gave for choosing Brazil as a destination were its large black population, and the prospect of having work documents and living freely. The question of language at first seemed an obstacle for some respondents, but this was an issue that had to be faced. 
Why is it so hard to belong? The difficulties of refugees in their integration processes within Brazilian society and labor market
Ana Christina Celano Teixeira | Eliana Cristina Motta da Silva Bourry Daniela Longobucco Teixeira Balog | Bianca Sá

I tried many times to escape to English speaking countries, but it was in vain...Brazil is the country with the second largest black population; thus, this had a significant impact (R7).

I looked for a country that spoke French, but I didn't succeed. The opportunity I had was in Brazil due to the visa (R4).

\section{Main obstacles to entering the Brazilian labor market}

Although Brazil is a signatory of the international human rights treaty and signed the United Nations' Refugee Convention in 1951 , soon after arriving in the country, respondents have perceived difficulties in adapting and their reception, including their entering the labor market. The most difficult aspects in entering the labor market have been the delay and disorganization in obtaining documents, a lack of financial support from the government to start a new life in the city, the difficulty of obtaining equivalency diplomas, the differences between the languages in various countries, and the absence of public policies related to this area.

\section{Refugee identity and documentation}

There is no doubt that the issue of documentation, which allows individuals to have their refugee identity recognized in the first place, seems to be the first major obstacle that they face. Local authorities themselves often do not recognize the documents that refugees receive upon arrival. But this lack of knowledge is widespread in society as a whole and ends up preventing refugees from even getting housing, not to mention opening bank accounts, enrolling in courses to continue their studies, and especially getting a job. The "eternal" condition of "being undocumented" as Villen (2016) puts it, reinforces the refugees" constant situation of existing as a marginalized being or, from another point of view, a hostile person (Santos, 2006).

My identity up until today has been a piece of paper that looks like a xerox copy, without a proper form and without any signature, which makes it difficult for businessmen to accept, since they neither know such a document nor my identity (R3).

The first obstacle was to open a bank account, but in the end, we were able to manage it (R6).

I was insecure during the period when they were analyzing the document sent by CONARE. This is because those who request visas do not know if, due to any change, after the analysis, the institution will validate the refugee status. This is a political matter and it leads to problems. It depends on the relations between countries and this may change in the middle of the process (R4).

\section{Differences between the educational system in Brazil and their countries of origin, equivalency diplomas and language differences}

Moroccan education is different from here. After high school you still have 2 years more to get a professional degree, and 3 years more to get an undergraduate degree (R2).

I tried to work in Nursing, my career at home, but I needed the equivalency diploma. It took a long time to get the equivalency diploma. I only got it after six years, and by then I was already working in another area (R4).

Brazil today offers some practical measures to encourage professional refugees arriving in this country. One of the measures is the teaching of Portuguese, through PRONATEC, with the offer of 400 vacancies in Rio de Janeiro and in São Paulo for those who are interested. In addition, the government indicates entrepreneurship courses. However, without money, many refugees do not have time to take courses, since they cannot stop working.

The question of language affects feelings of isolation and the difficulty of coexistence and integration, including the work sphere. As Kuhlman (1991) mentions, local integration should be the process through which refugees maintain their own identity, but they become part of the welcoming society if they can live with the local population in an acceptable manner. 
Why is it so hard to belong? The difficulties of refugees in their integration processes within Brazilian society and labor market
Ana Christina Celano Teixeira | Eliana Cristina Motta da Silva Bourry Daniela Longobucco Teixeira Balog|Bianca Sá

It can be noted from the interviews that social integration is prevented due to the language (Borjas, 1996) which can also be interpreted as a local obstacle or local resistance to multiculturalism (Rodrigo, 2012).

It was a difficult time. I was lost for 3 months. Only after this was I able to start to understand the context of sentences .... I had the opportunity to study Portuguese in a project at UERJ, but I was only able to go twice because I had to work.

I took 5 to 6 months for me to speak. I could speak from the need to survive. I learned from people on the streets, in the neighborhood. I did not have classes. I speak English, Germany, French, Haitian. None of these languages has helped me here (R8).

When I arrived here my wish was to find someone who could speak French so I could communicate (R4).

\section{Discrimination and prejudice}

Respondents pointed out that they had experienced explicit hostility and marginalization (Santos, 2006). Reports indicate that in addition to being affected by constant changes in the labor market, they also suffered discrimination for being refugees, often for being black, and also for being women. Based on the interviews, we see the Kantian principle of universal hospitality giving way to hostile situations (Bauman, 2016; Santos, 2006). In addition, we encountered the question of whether to consider the presence of multiculturalism from a local perspective, since there do not seem to exist any indicative reports of tolerance, which Rodrigo (2012) points out is the minimum feature for this condition. On the contrary, the interviews contain references to discrimination and even racism.

Hostility exists mainly in public bodies. The Federal Police does not like us. It is not only the Federal Police, and it is also not only prejudice. Refugees are viewed negatively because they are from poorer countries and because of racism. Other institutions see us as a threat (R8).

A refugee friend of mine, who is a white man, can get a job that should be mine, but being a woman and being black is an obstacle here (R4).

Sometimes I do not know if I could not get a job because I am a refugee or because I am black. I have never thought Brazil was such a racist country (R1).

Nobody accepted Venezuelans as refugees at the time and still today when Caritas calls us for interviews, they call us "Venezuelan refugees" (R3).

According to the interviewees' reports, even though Brazil has in its history incessant cultural and social relationships between different peoples (Freyre, 2006), the prejudice and the lack of equal coexistence between them, and today, their descendants, still stains the country. The absence of racial democracy, as well as persistent class and racial conflicts denounced by various authors in the social sciences (Almeida, 2019; Freitag, 2005; Ribeiro, 2017, 2019) can be observed in relationships with refugees. The cordial man from Holanda (2014) has not shown cordiality, tolerance or even offered an intercultural environment for refugees.

\section{Financial resources and work}

Most refugees arriving in Brazil come from difficult situations in their home countries and upon arrival need financial support, so being able to work immediately after their arrival determines their survival. Thus, they frequently do not have enough time to take a Portuguese course to facilitate communication.

It is worth remembering that we are currently experiencing a high rate of unemployment in Brazil and Rio de Janeiro according to IBGE statistics (2019), and this further worsens the refugee's employability situation. Thus, many of them start their professional activities in entrepreneurial careers, even though they have a master's degree or higher education.

In this sense, the results are aligned with Moulin (2013), who says that refugees are forced to accept jobs that do not require qualifications, even when they already bring training and know-how from their home nation. And indeed, despite existing 
public policies for placing refugees in the labor market, as stated by Moreira (2005), in practice, it seems that these are not so favorable to refugees. This is reinforced by the testimonials below from respondents with higher education.

(...) I started working on the street selling esfihas in front of Shopping Tijuca...I did not cook the esfihas, I bought them from some Syrians that I met at a church in Botafogo, and they gave me the opportunity to sell their products (R2).

(...) my first job was at a snack bar for six months (R3).

My spouse cooks very well and we decided to sell Lebanese food in JUNTA LOCAL's fairs and I helped her (R6).

Although an entrepreneurial career may seem to be a solution for many refugees, there are also difficulties in this area as can be seen in the following statements.

There is no financial support for those who want to start a new venture. So many people are interested in the matter, but nobody does anything to help us effectively. We are getting tired little by little. Many people from my community do not want to give interviews anymore because of this. We want a solution. It is no use giving knowledge if one cannot raise capital (R1).

I have always had my ideas. I've always wanted to have my own business. In the beginning I had an idea to open an NGO, but then I saw that searching for financial incentives in Brazil is too complicated. It employs different logic from my country. There was no business model. There was nothing (R8).

I knew how to braid hair, and this was my first job (R7).

\section{Social networking with other refugees as a means of facing the obstacles}

The obstacles identified by the refugees in establishing themselves in the local labor market are many and they could be observed in all of the interviews. However, in this daily struggle for survival in a foreign, hostile land, and in the middle of an economic crisis, the refugees unanimously identified getting together with people experiencing the same conditions or those of the same nationality as a valuable resource (Bauman, 2016; Moulin, 2018).

However, this tool of personal networking within their own communities further highlights the fragility of the multicultural model and its distance from interculturality. If respondents do not feel welcomed by local people and institutions, including the labor market and society, there remains only uniting with their own people as a strategy to face the situation. This personal networking, which at first glance seems positive, is limited to refugees and their own ethnic friends, and this may create even more difficulties in connecting and being included and may bring them even closer to the ghetto, taking on poor jobs which are of interest to no one (Nkomo et al., 2019; Rodrigo, 2012; Westwood \& Jack, 2009).

My family and friends helped me escape to Brazil... after two days in Rio de Janeiro I met some Congolese people that told me about the documents, about the city, the violence and this was very important to me (R4).

Part of my family is here, and my husband and I came to live with an 87-year-old cousin. The family network is everything and this is what makes the difference. Most of the things we learn are like this, one person teaches the others (R5).

If we do not help each other, who else will? We have to group together, together we are stronger. We are not afraid of working. To start with, it can be anything, but even like this, it is too difficult (R8). 


\section{CONCLUSION}

The study seeks to investigate the perception of refugees from various origins in terms of the processes and difficulties involved in integrating into Brazilian society and its labor market. The processes under focus deals with topics such as bureaucratic barriers, cultural differences, ethnic-racial issues and language, among others. Although we faced obstacles, mainly regarding scheduling interviews, and establishing a connection and trust with the respondents, we managed to organize their impressions. We believe that it is indispensable to observe the labor market issue and the dynamics established with this group in order to understand this social phenomenon within a broader context.

Regarding the perceived difficulties in entering the labor market, the following stand out: (1) the issue of the documentation and identification of refugees, which represent issues created by Brazilian government bodies in terms of time, clarity and efficiency; (2) discrimination, including racial discrimination from the population, employers and authorities; (3) teaching conditions, including Portuguese teaching, which is not efficient, and this creates barriers to the inclusion process through the labor market; (4) differences between educational systems and the equivalency diploma problem which in many cases remains unsolved; and (5) the creation of mechanisms to face obstacles through strong personal networking restricted to their own communities.

In general, the perceptions of the interviewed refugees explicitly express the view that the labor market in the city of Rio de Janeiro presents extreme difficulties, both due to the local economic crisis and the challenges imposed by their condition. Some think of training, others of entrepreneurship, but all at first were confident about finding future opportunities in Brazil and in the city.

The analyzed results allow us to consider that Brazil, as a signatory to the 1951 United Nations Refugee Convention which was ratified in 1997, guarantees asylum to foreigners and may at first appear to be an intercultural society, full of empathy and open to connecting and welcoming new people in an inclusive manner. However, in practice, this study from the point of view of the refugees paints a picture of detached institutional relations, combined with severe challenges of isolation, a lack of efficient public policies, and huge obstacles for refugees entering the labor market, which hardly allows us to assume that Brazil is a multicultural society let alone an intercultural one. 


\section{REFERENCES}

Aaker, D. A., Kumar, V., \& Day, G. S. (2009). Pesquisa de Marketing (2a ed.). São Paulo, SP: Atlas.

Almeida, S. L. (2019). Racismo estrutural. São Paulo, SP: Pólen.

Alto Comissariado das Nações Unidas Para os Refugiados. (2000). A situação dos refugiados no mundo: cinquenta anos de ação humanitária. Almada, Portugal: A Triunfadora Artes Gráficas.

Alto Comissariado das Nações Unidas Para os Refugiados. (2004). 2003 Global Refugee Trends: overview of refugee populations, new arrivals, durable solutions, asylum-seekers and other persons of concern to UNHCR. Retrieved from http://www.unhcr.ch

Alto Comissariado das Nações Unidas Para os Refugiados. (2018). Documento "Refúgio em números - 4o edição - 2018". Retrieved from https://www.acnur.org/portugues/wp-content/uploads/2019/07/ Refugio-em-nu\%CC\%81meros_versa\%CC\%83o-23-de-julho-002.pdf Amaral, E., \& FUSCO, W. (2005, June). Shaping Brazil: The role of international migration. Migration Information Source, 36, 1-10.

Andrade, J. (1996). A proteção internacional dos refugiados no limiar do século XXI. Travessia - Revista do Migrante, 25, 39-42.

Barbosa, F. H., Filho. (2017). A crise econômica de 2014/2017. Estudos Avançados, 31(89), 51-60.

Bauer, M. W., \& Aarts, B. (2002). A construção do corpus: um princípio para a coleta de dados qualitativos. In M. Bauer, \& G. Gaskell (Orgs.), Pesquisa qualitativa com texto, imagem e som (pp. 39-63). Petrópolis, RJ: Vozes.

Bauman, Z. (1998). O mal-estar da pós-modernidade. In Z. BAUMAN (Ed.), Inquietações da vida contemporânea e suas formas atuais de organização: uma relação de imanência. Rio de Janeiro, RJ: Jorge Zahar Ed.

Bauman, Z. (2017). Strangers at Our Door. Cambridge, UK: John Wiley \& Sons.

Bauman, Z. (2016). Living in an Age of Migration and Diasporas. In P. Ahponen, P. Harinen, \& V. S. Haverinen (Eds.), Dislocations of Civic Cultural Borderlines. Cham, UK: Springer.

Berchin, I. I., Valduga, I. S., Garcia, J., Salgueirinho, J. B., \& Guerra, O. A. (2017, August). Climate change and forced migrations: An effort towards recognizing climate refugees. Geoforum, 84, 147-150.

Borja, J. (1996). As cidades e o planejamento estratégico. Uma reflexão europeia e latino-americana. In T. Fischer (Org.), Gestão contemporânea. Cidades estratégicas organizações locais. Rio de Janeiro, RJ: Editora FGV.

Comitê Nacional Para os Refugiados. (2017). Cartilha "Protegendo refugiados no Brasil e no mundo". Retrieved from https://www.acnur. org/portugues/wp-content/uploads/2020/03/Cartilha-InstitucionalFinal_site.pdf

Creswell, J. W. W. (2010). Projeto de pesquisa: métodos qualitativo, quantitativo e misto (2a ed.). Porto Alegre, RS: Bookman.

Comitê Nacional Para os Refugiados. (2017). Portal Brasil. Retrieved from http://www.brasil.gov.br/@@search?Subject\%3Alist=Conare
Freitag, B. (2005). Florestan Fernandes: revisitado. Estudos Avançados, 19(55), 231-243.

Freyre, G. (2006). Casa-grande \& Senzala: formação da família brasileira sob o regime da economia patriarcal. São Paulo, SP: Global.

Friese, S. (2014). Qualitative data analysis with ATLAS.ti. London, UK: Sage Publications.

Gaskell, G. (2002). Entrevistas individuais e grupais. In G. GASKELL, \& M. W. BAUER (Orgs.), Pesquisa qualitativa com texto, imagem e som: um manual prático (pp. 64-89). Petrópolis, RJ: Vozes.

Hall, S. (2008). Da diáspora: Identidades e mediações culturais. Belo Horizonte, MG: Editora UFMG.

Haydu, M. (2009). Refugiados angolanos em São Paulo: entre a integração e a segregação. Ponto-e-vírgula, 5, 157-184.

Hobsbawm, E. (1995). Era dos extremos: o breve século XX. São Paulo, SP: Companhia das Letras.

Hobsbawm, E. (2017). A política da democracia. In E. HOBSBAWM (Ed.), A era dos impérios. Rio de Janeiro, RJ: Paz \& Terra.

Holanda, S. B. (2014). Raízes do Brasil. São Paulo, SP: Companhia das Letras.

Honneth, A. (2009). Crítica Del Agravio Moral: patologias de la sociedade contemporânea. Buenos Aires, Argentina: Fundo de Cultura Economica, Univesidad Autonoma Metroplitana.

Instituto Brasileiro de Geografia e Estatística. (2019). Estatísticas Sociais, 2019. Rio de Janeiro, RJ: Author.

Jack, G., \& Westwood, R. (2009). International and Cross-Cultural Management Studies. London, UK: Palgrave Macmillan.

Kuhlman, T. (1991, February). The Economic Integration of Refugees in Developing Countries: A Research Model. Journal of Refugee Studies, 4(1), 1-20.

Ministério da Justiça. (2010). Refúgio no Brasil: a proteção brasileira aos refugiados e seu impacto nas Américas. Brasília, DF: Author.

Moreira, J. B. (2005). Problemática dos refugiados na América Latina e no Brasil. Brazilian Journal of Latin America Studies, 4(7), 57-76.

Moreira, J. B. (2010, julho). Redemocratização e direitos humanos: a política para refugiados no Brasil. Revista Brasileira de Política Internacional, 53(1), 111-129.

Moreira, J. B. (2012). Política em relação aos refugiados no Brasil (1947-2010) (Doctoral Dissertation). Universidade Estadual de Campinas, Campinas, SP.

Moulin, C. (2013, September). Protection and vulnerability in urban contexts: the case of refugees in Rio de Janeiro (Discussion Paper 6). Rio de Janeiro, RJ: Hasow.

Moulin, C. (2011). Eppur si muove: mobilidade humana, cidadania e globalização. Contexto Internacional, 33(1), 9-17.

Nkomo, S. M., Bell, M. P, Roberts, L. M., Joshi, A., \& Thatcher, S. M. B. (2019, July). Diversity at a Critical Juncture: New Theories for a 
Why is it so hard to belong? The difficulties of refugees in their integration processes within Brazilian society and labor market
Ana Christina Celano Teixeira | Eliana Cristina Motta da Silva Bourry Daniela Longobucco Teixeira Balog | Bianca Sá
Complex Phenomenon. Academy of Management Review, 44(3), 498-517. Retrieved from http://dx.doi.org/10.5465/amr.2019.0103

Paiva, A. R., Dias, A. C. S., \& Moulin, C. (2018). Migrações e refúgio: travessias interdisciplinares, desafios globais. $O$ social em questão, 21(41), 9-22.

Pellegrino, A. (2003). La migración internacional em América Latina y el Caribe: tendencias y perfiles de los migrantes. Washington, DC: United Nations Publications.

Póvoa, H., Neto, \& Ferreira, A. P. (2005). Cruzando fronteiras disciplinares: um panorama dos estudos migratórios. Rio de Janeiro, RJ: Revan.

Ribeiro, D. (2015). O povo brasileiro: a formação e o sentido do Brasil. São Paulo, SP: Global.

Ribeiro, D. (2017). O que é lugar de fala?. Belo Horizonte, MG: Letramento.

Rodrigo, M. (2012). La Comunicación Intercultural. Barcelona, España: Anthropos.

Santos, B. D. S. (2003). O mundo resiste. Revista Caros Amigos, 78, 34-38.
Santos, B. S. (2006). “Una nueva cultura política emancipatoria." In B. $\mathrm{S}$. Santos (Ed.), Renovar la teoría crítica y reinventar la emancipación social: encuentros en Buenos Aires. Buenos Aires, Argentina: Universidade de Buenos Aires.

United Nations High Commissioner for Refugees. (2015). UNHCR Global Trends. Retrieved from www.unhcr.org/statistics/.../unhcrglobal-trends-2015.html

United Nations High Commissioner for Refugees. (2016). Worldwide displacement hits all-time high as war. Retrieved from www.unhcr. org/.../worldwide-displacement-hits-all-time-high-war-2016.html

United Nations High Commissioner for Refugees. (2019). Dados sobre Refúgio 2019. Retrieved from https://www.acnur.org/portugues/ dados-sobre-refugio/

Villen, P. (2016, dezembro). "Fronteiras porosas" e a explosão da mobilidade indocumentada. Argumentum, 8(3), 29-39. Retrieved from http://dx.doi.org/10.18315/argumentum.v8i3.14711

Zanini, M. C., Póvoa, H., Neto, Santos, M. (2013). Migrações internacionais: Valores, capitais e práticas em deslocamento. Santa Maria, RS: Editora UFSM.

Ana Christina Celano Teixeira

ORCID: https://orcid.org/0000-0001-9721-0626

Ph.D. in Administration from Fundação Getulio Vargas (FGV EBAPE); Full professor at IBMEC. E-mail: ana.teixera@ibmec.edu.br

Eliana Cristina Motta da Silva

ORCID: https://orcid.org/0000-0002-1384-3889

Master of Business Administration from IBMEC. E-mail: contato@elianamotta.com

Daniela Longobucco Teixeira Balog

ORCID: https://orcid.org/0000-0002-0003-8311

Ph.D. student and Master in Administration from the University of Grande Rio (UNIGRANRIO). E-mail: dlongobucco@gmail.com

Bianca Sá

ORCID: https://orcid.org/0000-0002-0177-6869

Master in Administration from IBMEC/RJ; Ph.D. student in Business Administration at Fundação Getulio Vargas (FGV EBAPE).

E-mail: bassisrangel@gmail.com 